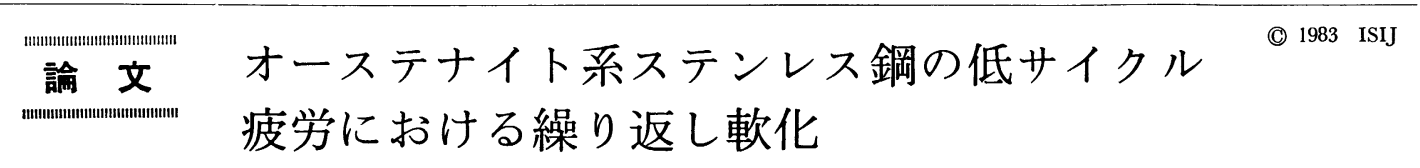

\author{
柴田浩司* ·名村夏樹 ${ }^{* 2} \cdot$ 岸本康夫 ${ }^{* 2} \cdot$ 藤田利夫*
}

\title{
Low Cyclic Fatigue Softening of Austenitic Stainless Steels
}

Koji Shibata, Natsuki Namura, Yasuo Kishimoto, and Toshio Fujita

\begin{abstract}
Synopsis :
Low cyclic fatigue behavior of some $18 \mathrm{Cr}-8 \mathrm{Ni}$ and $25 \mathrm{Cr}-20 \mathrm{Ni}$ austenitic stainless steels has been studied. Cyclic softening was observed after the initial cyclic hardening in all the steels investigated. The formation of $\alpha^{\prime}$ martensite during the cyclic deformation depressed the softening and introduced the second hardening. The softening was revealed remarkably by nitrogen addition, and solute carbon also produced large softening but to a lesser degree than nitrogen. The cyclic softening occured especially in the surface layer of the specimens, and more slip bands were observed at the surface of the specimens showing the remarkable softening. A planar structure of dislocations was produced and a cell structure was scarcely observed in all the steels showing the large softening, while dislocations tended to form a cell or a band structure in the steels showing the small softening. The planar structure might enhance the cyclic softening through increasing the Bauschinger effect, the density of mobile dislocation, and/or the number of the slip band. The tendency of dislocations to form the planar structure could not be explained only with the stacking fault energy. The large cyclic softening observed in this study seemed to increase the fatigue life. In the case of stress controlled tests, however, the lives of the steel showing the significant softening were shorter, when they were compared at about the same strength ratio of the applied stress to $0.2 \%$ proof stress or ultimate tensile strength.
\end{abstract}

\section{1. 緒}

言

金属材料の疲労過程はき裂の発生までの段階（疲労損 傷過程）とその後のき裂の成長の段階（き裂伝ぱ過程） に大別できる. 一般に疲労寿命の大部分がき裂の伝ぱに 費やされることから，き裂の伝ぱに関して多くの研究が なされているが，材料の安全性に対する要求がますます 高まつている今日, 疲労損傷過程を十分明らかにしてお くことも重要である1).

従来金属材料の疲労損傷過程については,主として $\mathrm{Cu}$ 合金, Al 合金に打いて詳しく調べられている.鉄鋼材 料に関する研究は, 純鉄, 炭素鋼などで比較的多くみら れるが，オーステナイト（r）系鋼に関する研究は少な く不明の点が残されている。例觉ば $\gamma$ 系ステンレス鋼 の溶体化処理材は繰り返し硬化を示すという報告2) 4)の 他に，繰り返し軟化も示すという報告5) 8)があるが，系 統的な研究はなく繰り返し軟化の生成条件, 生因などに ついてはほとんど検討されていない， $\gamma$ 系鋼の溶体化処 理材が繰り返し軟化を示すといらことは, 疲労損傷に関 する一般的な説明で単純に理解できる現象ではなく，ま
た疲労特性が本系鋼を用いる際の重要な設計基準となる 場合もあることを考学ると, 繰り返し軟化の生因, 寿命 に及ぼす影響などを明らかにすることは重要であると考 えられる. そこで本研究では, 各種 $\gamma$ 系ステンレス鋼 の低サイクル疲労挙動とくに繰り返し塑性挙動を主とし て室温で観察し, 繰り返し軟化に関する詳細を明らかに することを目的として実験を行つた.

\section{2. 実 験 方 法}

Table 1 亿供試鋼の化学成分を示す. 304, 310S 鋼 はそれぞれ SUS 304, SUS $310 \mathrm{~S}$ 鋼に相当する鋼, 304

Table 1. Chemical composition of steels (wt \%).

\begin{tabular}{|c|c|c|c|c|c|}
\hline steels & C & $\mathrm{Ni}$ & $\mathrm{Cr}$ & $\mathrm{Al}$ & $\mathrm{N}$ \\
\hline 304 & 0.049 & 8. 84 & 18.44 & 0.014 & 0.009 \\
\hline $304 \mathrm{~N}$ & 0.051 & 8.82 & 18.51 & 0.024 & 0.160 \\
\hline $310 \mathrm{~S}$ & 0.027 & 19.84 & 24. 96 & 0.007 & 0.010 \\
\hline $310 \mathrm{SN}$ & 0.034 & 20.18 & 24. 53 & 0.011 & 0.174 \\
\hline $310 L^{*}$ & 0.011 & 20.11 & 25.06 & 0.004 & 0.008 \\
\hline $310 \mathrm{C}^{*}$ & 0.180 & 19.91 & 24.91 & 0.003 & 0.007 \\
\hline $310 N^{*}$ & 0.013 & 20.21 & 24.85 & 0.004 & 0.170 \\
\hline
\end{tabular}

昭和 56 年 11 月本会講演大会にて発表 昭和 58 年 1 月 20 日受付 (Received Jan. 20, 1983)

* 東京大学工学部 工博 (Faculty of Engineering, The University of Tokyo, 7-3-1 Hongo Bunkyo-ku 113)

*2 東京大学大学院 (現 : 川崎製鉄 (株)) (Graduate School, The University of Tokyo, Now Kawasaki Steel Corp.) 
$\mathrm{N} ， 310 \mathrm{SN}$ 鋼はそれぞれ 304，310S 鋼にNを添加した ものである. $310 \mathrm{~L}, 310 \mathrm{C}$ および $310 \mathrm{~N}$ 鋼は $\mathrm{C}$ と $\mathrm{N}$ 影響を分離してみるために真空溶解したもので，それぞ 水低 $\mathrm{C}$ 低 $\mathrm{N}, \mathrm{C}$ 添加低 $\mathrm{N}, \mathrm{N}$ 添加低 $\mathrm{C}$ の $25 \mathrm{Cr}-20 \mathrm{Ni}$ 系鋼である.鋼塊を鍛造，圧延して得られた $15 \mathrm{~mm}$ 厚 の板あるいは $13 \mathrm{~mm} \phi$ の棒を $1323 \mathrm{~K}$ あるいは 1573 $\mathrm{K} て ゙ 1 \mathrm{~h}$ 溶体化処理後水冷したのち試験片に加工した. 試験片は平行部径 $5 \mathrm{~mm} \phi$, 平行部長 $10 \mathrm{~mm}$ の丸棒で ネジ部は外径 $12 \mathrm{~mm} \phi$ である. 加工後クロム酸十りん 酸液にて電解研磨してから試験に供した†。

疲労試験扰よび引張試験はインストロン型試験機を用 いクロスーッド速度 $2 \mathrm{~mm} / \mathrm{min}$ で行つた．疲労試験は 完全両振りの引張り・圧縮三角波を与兄, 応力振幅ある いは全ひずみ振幅を一定に制御して行つた。ひずみは試 験片の平行部にとりつけたクリップオンゲージにて検出 した. 疲労試験後透過電子顕微鏡を用いて繰り返し変形 材の微視組織を観察した。 また走査型電子顕微鏡による 試験片表面の 損賃の 観察も行つた. 繰り返し 変形中に $\alpha^{\prime}$ マルテンサイトが生じたかどらかは, 振動型磁力計 を用いて測定した繰り返し変形材の磁化率扰よび透過電 子顕微鏡観察による組織から判断した.

\section{3. 実験結果および考察}

\section{1 繰り返し硬化・軟化举動之微視組織}

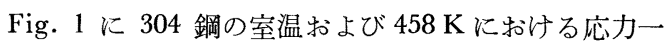
定試験の結果を示す。縦軸は塑性ひずみ振幅であるが， 458K においては初期絽り返し硬化ののち繰り返し軟化 が観察される，この温度では $\alpha^{\prime}$ マルテンサイトの生成 は認められない，室温においても初期繰り返し硬化のの ち軟化が認められるが，再び硬化する．磁化率の測定， 組織観察から,繰り返し軟化後再び硬化する段階では $\alpha^{\prime}$ マルテンサイトが盛んに生じていることがわかつた.

Fig. 2 は $304 \mathrm{~N}$ 鋼の全ひずみ一定試験結果である. 初期繰り返し硬化ののち軟化が著しい。この鋼に执いて も応力一定試験を行つたが，304 鋼の場合より著しく大 きな繰り返し軟化が観察された，他の鋼において子認め られることであるが，繰り返し軟化の程度は一般に応力 一定試験に打ける注らがひずみ一定試験におけるより明 瞭にあらわれる．これは前者の繰り返し变形の場合繰り 返し軟化が生じるとひずみの振幅が大きくなり，ますま 寸軟化を助長することによるものと考觉られる.

304 鋼の室温における繰り返し变形材の微視組織は繰

†加工あるいは電解研磨の影響をみるため試験片を電解研磨後石英管に 真空封じし, 溶体化処理（水水中に㶹入れ）したものについても繰り 返し塑性挙動を観察したが相違はほとんど見られなかつた。

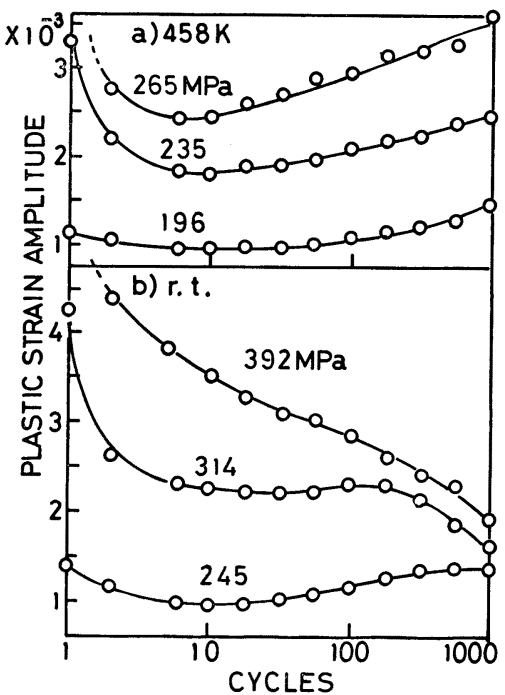

Fig. 1. Plastic strain amplitude response of 304 steel for constant stress amplitude tests at (a) 458 $\mathrm{K}$ and (b) room temperature (r. t.).

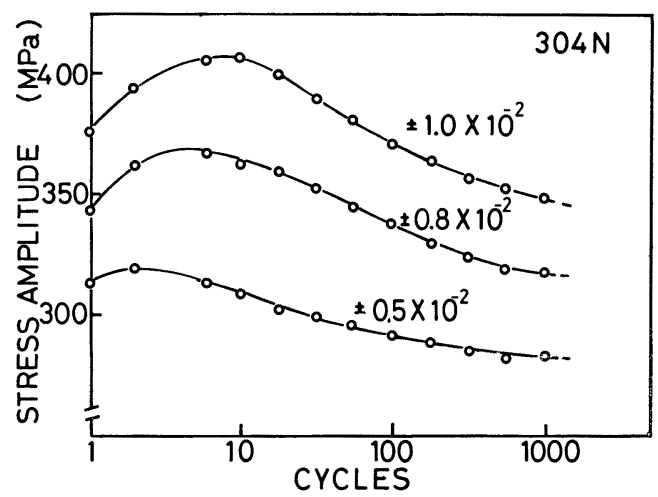

Fig. 2. Stress amplitude response of $304 \mathrm{~N}$ steel for constant total strain amplitude tests at room temperature.

り返し変形の初期では平面状の（planar）転位構造とな り, 繰り返し数が増えるにつれてバンド状9) の転位構造 一移行する、ひずみ振幅, 応力振幅が大きいととマルテ ンサイト， $\alpha^{\prime}$ マルテンサイトが多く生じる，458K で はマルテンサイトは生じず，Photo．１亿示すように応 力（あるいはひずみ）振幅が小さいと平面状組織あるい はバンド状組織が，振幅が大きいとセルができやすい。

Photo. 1 には $304 \mathrm{~N}$ 鋼の室温に打ける結果も示すが, この鋼では応力（あるいはひずみ）振幅が大きくてもセ ルは生じにくく平面状の転位構造が多く観察される.

Fig. 3 は $310 \mathrm{~S}$ 鋼と $310 \mathrm{SN}$ 鋼の全ひずみ一定試験 の結果を比較して示したものである. この場合も $\mathrm{N}$ 添加 

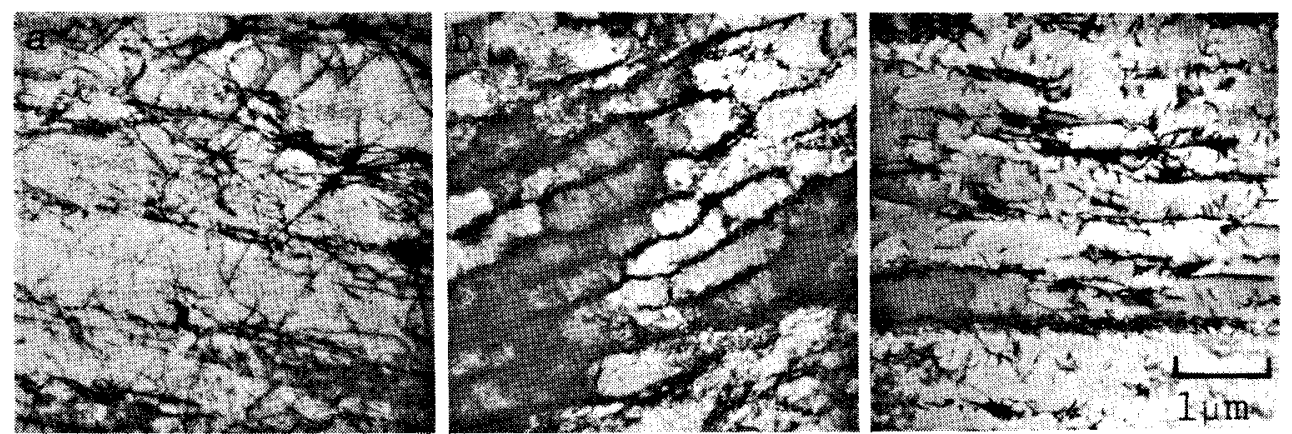

(a) $304,458 \mathrm{~K}, \pm 196 \mathrm{MPa}, 1000$ cycles, (b) $304,458 \mathrm{~K}, \pm 274 \mathrm{MPa}, 1000$

cycles, (c) $304 \mathrm{~N}$, room temperature, $\pm 323 \mathrm{MPa}, 4000$ cycles.

Photo. 1. Microstructure observed after cycling.

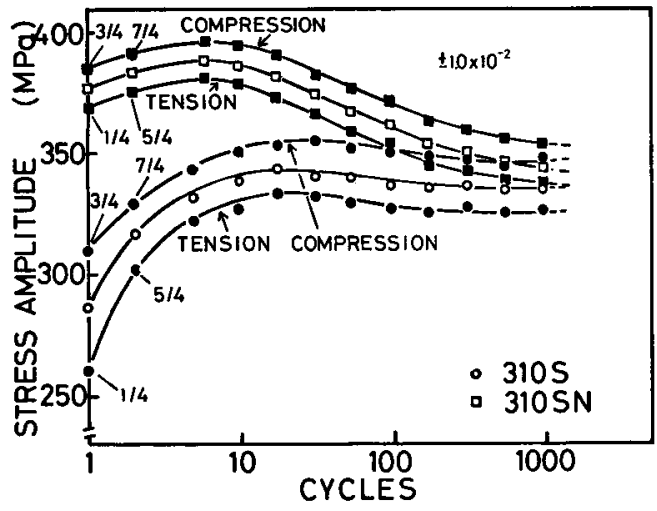

Fig. 3. Stress amplitude response of $310 \mathrm{~S}$ and 310 SN steels for constant total strain amplitude tests at room temperature.

鋼の繰り返し軟化が大きい。この図には繰り返し変形中 の最低応力 (絶対值) および最高応力の変化をそれらの 平均値すなわち応力振幅の変化とともに示した。これら は繰り返し变形中にほ泳同様の挙動を示すことがわか る.

Fig. 4 は $310 \mathrm{~L}, 310 \mathrm{C}, 310 \mathrm{~N}$ 鋼の $1323 \mathrm{~K}$ 溶体化 処理材の全ひずみ一定試験の結果である. $310 \mathrm{~L}, 310 \mathrm{C}$ 鋼では $310 \mathrm{~S}$ 鋼と同椂な応力振幅の変化がみられ繰り 返し軟化はほんのわずか認められる程度である。一方， $310 \mathrm{~N}$ 鋼では $310 \mathrm{SN}, 304 \mathrm{~N}$ 鋼同样初期繰り返し硬化の のち顕著な軟化が認められる.

$310 \mathrm{C}$ 鋼の $1323 \mathrm{~K}$ 溶体化処理材では未固溶炭化物が 多く観察され，結晶粒径む他の 2 鋼が $40 \mu$ 程度である のに対し約 $10 \mu$ と著しく小さい：そこで炭化物を固溶 させた場合の効果, 結晶粒径の效果を明らかにするため K, $1573 \mathrm{~K} \times 1 \mathrm{~h}$ の溶体化処理材について子疲労試験を 行つた。結晶粒径は 3 鋼種ともおよそ $350 \mu$ となる。疲 労試験結果を Fig. 5 と示す. $310 \mathrm{~L} ， 310 \mathrm{~N}$ 鋼の繰り

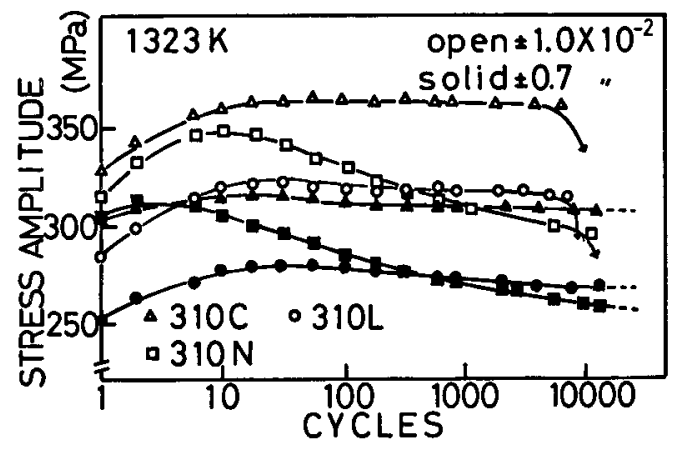

Fig. 4. Stress amplitude response of $310 \mathrm{~L}, 310 \mathrm{C}$, and $310 \mathrm{~N}$ steels solution treated at $1323 \mathrm{~K}$ for constant strain amplitude tests at room temperature.

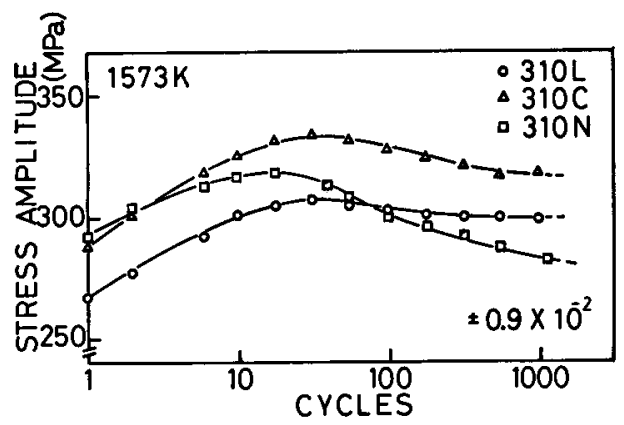

Fig. 5. Stress amplitude response of $310 \mathrm{~L}, 310 \mathrm{C}$, and $310 \mathrm{~N}$ steels solution treated at $1573 \mathrm{~K}$ for constant strain amplitude tests at room temperature.

返し塑性挙動は $1323 \mathrm{~K}$ 溶体化の場含とあまり変わらな いのに対し，310C 鋼では $310 \mathrm{~N}$ 鋼はどではないが比 较的大きな繰り返し軟化が生じるよらになる。

Photo. 2 は 310 系鋼の繰り返し変形材の微視組織で ある. 310L 鋼では $1323 \mathrm{~K} ， 1573 \mathrm{~K}$ 溶体化材とも七 ルの形成が著しく, 結晶粒が大きくなつても転位が平面 

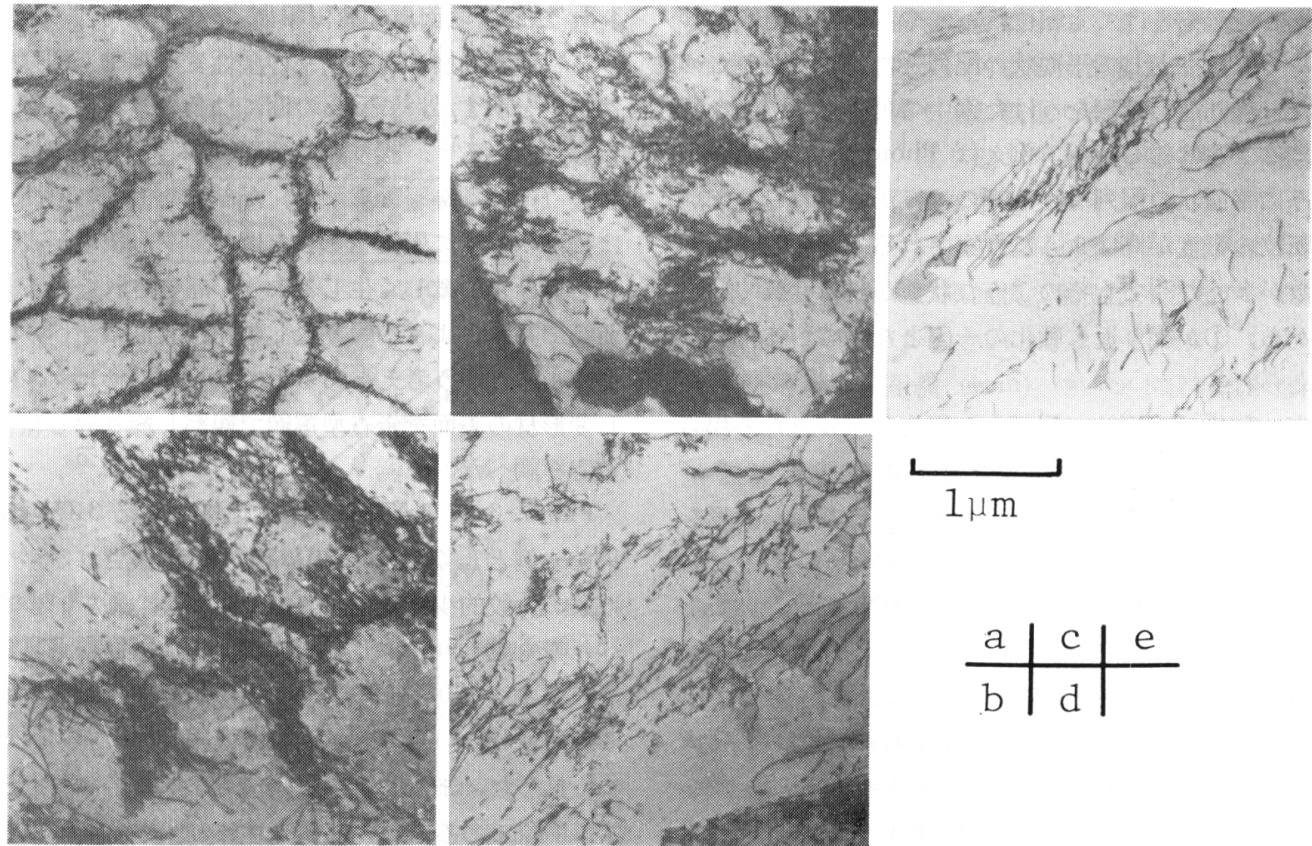

(a) $310 \mathrm{~L}(1323 \mathrm{~K}), 13000$ cycles, (b) $310 \mathrm{~L}(1573 \mathrm{~K}), 1000$ cycles, (c) $310 \mathrm{C}(1323 \mathrm{~K})$, 13000 cycles, (d) $310 \mathrm{C}(1573 \mathrm{~K}), 8300$ cycles, (e) $310 \mathrm{~N}$ (1323K), 13000 cycles.

Photo. 2. Microstructure observed after cycling at $0.7 \times 10^{-2}$ strain amplitude.

状に配列しやすくなるといらような傾向 ${ }^{\mathbf{1 0})}$ 㥜められな かつた. $310 \mathrm{C}$ 鋼では $1323 \mathrm{~K}$ 溶体化の場合セルが多く 見られたが，1573K 溶体化の場合は平面状の転位配列 が多くなりセルは少なくなる．310N 鋼では溶体化温度 によらず平面状の転位配列が括もに観察される。以上か ら固溶 $\mathrm{C}$ も程度は小さいが $\mathrm{N}$ と同様の効果を有するこ と, 結晶粒径の効果は大きくないことがわかる。

\section{$3 \cdot 2$ 繰り返し軟化とバウシンガー効果}

前加工, 析出, マルテンサイト変態などで強化されて いない材料の繰り返し軟化の生因としては, (1)可動転位 密度の増加, (2) 塑性変形領域 (リューダース帯) の拡 大，(3)ごく初期の繰り返し変形により導入された転位の 再配列, (4)軟化領域である表面のすべり帯の増加, など が提晿されている11). また(5)バウシンガー効果が大きい ことが繰り返し軟化の一因となることも考光られる ${ }^{12)}$. これらのらら(2)については，室温に扫ける $\gamma$ 系ステン レス鋼の応力ーひずみ曲線にリューダース伸びが認めら れないことなどから除外できる. (3)についても, 本研究 で用いた $\mathrm{N}$ 添加鋼で繰り返し变形のごく初期から平面状 の転位配列が観察されたことから，それらの鋼の著しい 繰り返し軟化の主要な原因とは考兄られない。しかし初 期繰り返し硬化ののちわずか軟化し飽和状態に移るよう な場合は, 初期の繰り返し変形によつて導入された転位

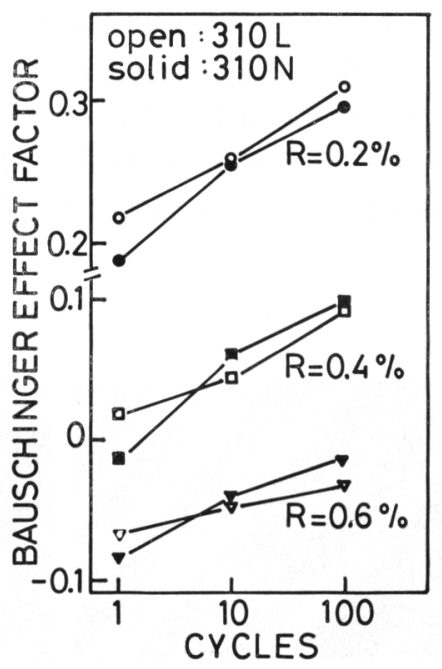

Fig. 6. Change in the Bauschinger effect factor ${ }^{14}$ ) during cyclic deformation at $0.9 \times 10^{-2}$ total strain amplitude.

がセルへと整理されていくのが観察されるので，この機 構が軟化の 1 つの原因として考光られる. (4)については 次節で検討することにして，ここでは(1)扣よび(5)にうい て考察する.

前節で述べたように大きな繰り返し軟化を示す鋼では 
繰り返し変形をらけても耺位はセルやバンド状組織をつ くりにくく，主として平面状の配列となることが確かめ られた，繰り返し変形をうけた鋼中の可動転位密度を正

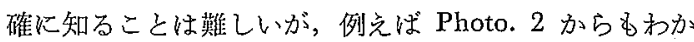
るように平面状の配列をとる鋼の注うがもつれ合つてい ない転位の密度が高いように観察される。そのう繰り 返し数が多くなつてもその上らな状態少維持されている ことから，(1)が繰り返し軟化の一因となつている可能性 も考光られる。

一方，転位か称面状に配列した場合，セルとなる場合 より大きなバウシンガー効果を生じると言われてい る13)、繰り返し変形の湯合もそれまでの繰り返し卒形を 前加工と考光れば一種のバウシンガー効果が生じること が教兄られる．Fig. 6 は $310 \mathrm{~L} ， 310 \mathrm{~N}$ 鋼においてそ の上うな効果が繰り返し变形によつてどう変化するかを MATAYA らの方法14)たならて示したものである。縦 軸は引張応力のピーク值を $\sigma_{\mathrm{P}}$ ，圧縮時の塑性ひずみ $R$ に刘する圧縮応力の值を $\sigma_{\mathrm{R}}$ としたときの $\left(\sigma_{\mathrm{P}}-\sigma_{\mathrm{R}}\right) / \sigma_{\mathrm{P}}$ なるバウシンガー效果因子 (B. E. F.) である.同じ $R$ で比校したときこの値が大きいほどこの種のバゥシンが 一效果が大きいと言える。耐鎆ともR の大きさにかか わらず B. E. F.はは忙め小さく繰り返し変形ととあに 增加するが，繰り返し初期では 310 L 鋼の B. E.F.の 汪らが大き繰り返し数が增すと逆転する傾向が見られ る.とくに $R$ が大きい場合その傾向が大きい。禹鍓の こうした B.E. F. の挙動は，転位組織の形態・応力反 䎐炕対する安定性などと密接関連している ${ }^{14)}$ ものと考 克られる。

\section{$3 \cdot 3$ 試験片表面層の疲労損照}

材料の表面層は材料内部の塑性変形挙動と関連した塑 性挙動を示すが，これらの間には多少差があることが報 告されている ${ }^{15)}$ ．繰り返し変形関してもすべり様式の 相違（セル型か平面状型か）汃試験片表面の们凸㘯るい は損傷の程度に影響すること年) 18)や，椇傷が表面層に 招いてとくに激しく生じることが報告されている。 未た 前節でふれたように繰り返し軟化は表面のすべり带の増 加によるといら侾えあるので，1000 サイクル繰り返 し夜形材の表面を走查型電顕で観察し繰り返し軟化との 対応を調べた。

Photo. 3 飞 $1573 \mathrm{~K}$ で溶体化処理した 310 系鋼の結 果を一例として示す． $310 \mathrm{~L}$ 鋼では観察されるすべり帯 の数が比較的少なく，直線性が $310 \mathrm{~N}$ 銓より小さいす ベり带も見られる。鳥いに交美するすべり带も見られる が一方のすべり帯は全体に $310 \mathrm{~N}$ 鋼の場合洼ど 明瞭に は観察されない. $310 \mathrm{~N}$ 鋼では直線性のよいすべり帯が 多く見られ，また互い交美するすべり帯は双方とる全 体に明瞭である. $310 \mathrm{C}$ 鋼のすべり帯は $310 \mathrm{~L}$ 鋼と 310 N鋼の場合の中間的な様相を示している.ず゙り帯に沿 つた入り込みあるいは微視き裂，突き出しと考光られる 個所は，310L 鋼に括いて他の鋼上り多く観察された。

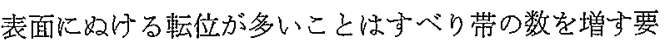
因となるであるらから，310N 鋼で多くのすべり帯が観 察されることは，この鋼の繰り返し変形材で可動転位密 度が高いように見られた組織観察の結果と対応するよう 飞考克られる。乙玑平面状の転位配列をとる場合，す ベり帯の凹凸が鋭くなり ${ }^{16)}$ 観察にかかりやすくなつてい ることも考允られ、いずれたよりすべり帯が多く観察
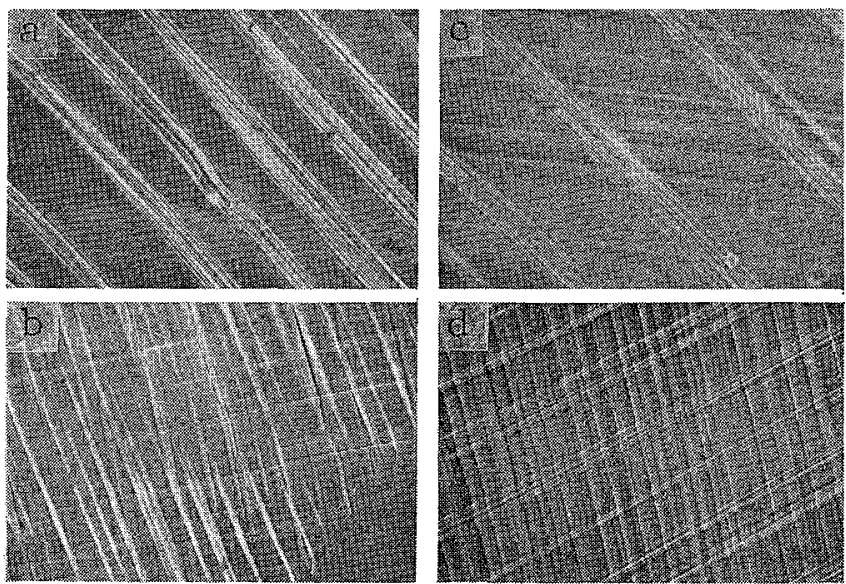

Photo. 3. Slip bands on the surface of (a, b) 310L, (c, d) $310 \mathrm{C}$, and (e, f) $310 \mathrm{~N}$ steels after 1000 cycles at $0.9 \times 10^{-2}$ strain amplitude. (solution treatment : $1573 \mathrm{~K} \times 1 \mathrm{~h}$ ) 


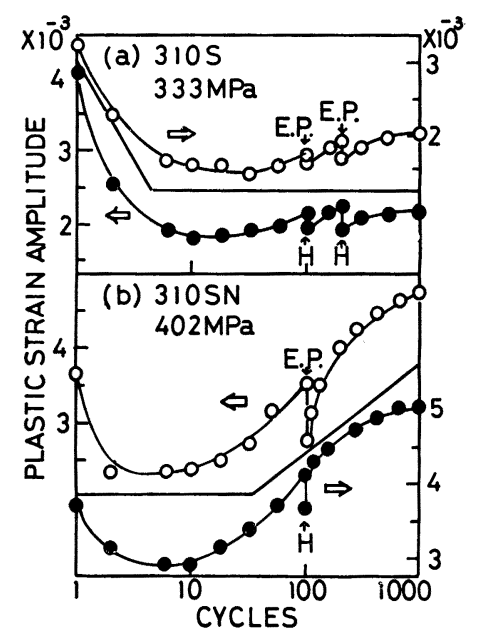

Fig. 7. Effect of intermediate surface removal on strain amplitude response. (E. P.=electrolitic polishing, $\mathrm{H}=$ heating at $353 \mathrm{~K}$ for $30 \mathrm{~min}$ )

されるのかは, 表面近傍での転位配列やすべり帯のさら に微細な構造を観察していないので明らかではない.ど ちらにしても繰り返し軟化の大きな鋼ほど明膫に観察さ れるすべり帯の数が多いことがわかつたので，つぎに表 面に批ける損傷と繰り返し軟化との関係を明らかにする ため以下のような実験を行つた。

すなわち応力一定試験において繰り返し軟化を示す繰 り返し数で試験を中断し, 試験片の表面を約 $100 \mu$ 電解 研磨した後再び絽り返し変形を加えてひずみ振幅の变化 を観察した. 電解研磨の際の温度上昇の効果をみるため 電解研磨時と同様の加熱処理をほどこしたものについて も同じような試験を行つた. Fig. 7 に $310 \mathrm{~S}, 310 \mathrm{SN}$ 鋼 の結果を示すが, $310 \mathrm{~S}$ 鋼では電解研磨を行つたもの之 加熱だけのものとの間で, 繰り返し変形を再開した後の 曲線の様子にほとんど差が見られない，またこれらの曲 線と繰り返し変形中断前の曲線の延長線との間にずれが 認められるが，この程度のずれは試験片を取りはずした だけで研磨も加熱も行わずに繰り返し変形を再開した場 合でも認められる. 他方 $310 \mathrm{SN}$ 鋼では表面層を除去す ると加熱だけ行つたものよりも大きなひずみ振幅の減少 が認められる. また加熱だけの場合は繰り返し変形再開 の際, ひずみ振幅の曲線が繰り返し変形中断前の曲線の 延長線のレベルあるいは形状まですみやかにもどるのに 対して, 電解研磨した場合はより多くの繰り返し数が必 要である．以上より繰り返し軟化はとくに試験片の表面 層で著しく生じていることが示唆される.

\section{4 転位の平面状配列と栍層欠陥エネルギー}

前述したように顕著な繰り返し軟化が認められる場合

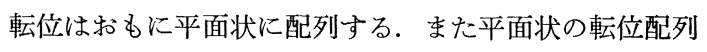
はバゥシンガー効果, 可動転位密度あるいはすべり帯の 密度を増大させ繰り返し軟化に寄与する可能性のあるこ とが考察された．繰り返し変形材の転位配列の様式を決 める因子として積層欠陷エネルギー (s. f. e.) が重要 であることはよく知られて和り 19) 22)，例光ば LUKASら は低 s. f. e. 材では平面状の転位配列となり, 高 s. f.

e. 材ではひずみが大きいときセル組織が，ひずみが小 さいとき葉脈状組織（vein）やバンド状組織が形成され るとしている.

比較的最近の報告 ${ }^{23)}$ 25) とよると, SUS 304 鋼の室温 に打ける s. f. e. は $15 \sim 25 \mathrm{erg} / \mathrm{cm}^{2}$, SUS $310 \mathrm{~S}$ 鋼の s. f. e. は $30 \sim 45 \mathrm{erg} / \mathrm{cm}^{2}$ 程度であり, $\gamma$ 系ステンレ ス鋼の s. f. e. 亿及ぼす N 添加の影響についてみると s. f. e. は低下寸るとする報告がほとんどである2627). したがつて本研究で観察された $\mathrm{N}$ 添加鋼の平面状転位配 列は，N添加による s. f. e. の低下から説明できるよう

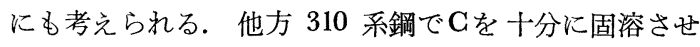
ると繰り返し軟化の程度が増大するとともに，転位はセ ルを形成するより平面状に配列する傾向を強めることが 観察された. しかしGの添加により $\gamma$ 系ステンレス鋼 の s. f. e. が低下するという報告はみられない。すなわ ち s. f. e. だけで転位配列の形態の違いを説明すること はできない. Swann ${ }^{10)}$, Douglass ら ${ }^{28)}$ も レス鋼の転位配列は s. f. e. の高低だけで説明できない として， $\mathrm{Cr}$ あるいは $\mathrm{Fe}$ 原子と $\mathrm{N}$ 原子との強い親和力 による短範囲規則格子の形成とその効果から転位が平面 状に配列する機構を説明しょらとしている，それは一般 に転位が一度通過して短範囲規則格子が壞れると同じす べり面を他の転位が通りやすくなるため, 平面状の転位 配列となるとされているからである。一方西沢29) は $\gamma$ 鋼 中の金属元素と $\mathrm{N}, \mathrm{G}$ との結合エネルギーの文献值を整 理して示しているが，それによると $\mathrm{N} ＼textrm{C}$ は $\mathrm{Cr}$ と強 い結合力を有するが $\mathrm{Cr}$ と $\mathrm{N}$ 結合力の注らが強い. し たがつてもし短範囲規則格子が形成されるのならばNの ほうがその傾向が強いこと，しかし $\mathrm{G}$ も同様の作用を有 することが推察される.この推察は $310 \mathrm{~N}$ 鋼や Cをを十 分に固溶させた $310 \mathrm{C}$ 銅における転位配列および 繰り 返し軟化の程度に関する本研究の観察結果と定性的に一 致する. しかしこのような短範囲規則格子が $\gamma$ 系ステ ンレス鋼で生じることは実証されておらず，また $\gamma$ 系鋼 に怙ける $\mathrm{C}, \mathrm{N}$ の固溶強化機構に関しては不明の点が多 い30ことを考光ると, さらに詳しい研究を行う必要があ る. 


\section{5 繰り返し軟化と疲労寿命}

繰り返し軟化あるいは硬化が疲労寿命に及ぼす影響に ついては, 実用上重要な問題として繰り返し変形によつ て導入される転位構造の違いの効果などとも関連させて 議論されている31)32). しかし $\gamma$ 系ステンレス鋼に関す る研究は, 疲労き裂伝播速度に及ぼす $\mathrm{N}$ 添加の影響につ

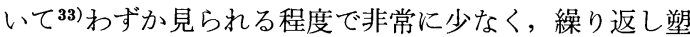
性挙動との関連など詳細については検討されていない， そこでまず $310 \mathrm{~L}$ 鋼と $310 \mathrm{~N}$ 鋼を用い室温において ひずみ一定試験を行つて寿命を比較した．結果を Table 2 に示すが，測定したすべてのひずみ振幅で，顕著な軟 化を示す $310 \mathrm{~N}$ 鋼の寿命が長いことがわかる．この結 果は $\mathrm{Al}$ 合金, $\mathrm{Cu}$ 合金などで報告されている32) 寿命に 及ぼす繰り返し軟化，平面状の転位構造の効果と対応し ている.

一方, 低サイクル疲労寿命は材料の静的な強度, 延性 あるいは勒性と関連することが指摘され，静的な引張強 度, 延性・勒性から疲労寿命を推定する式がいくつか提 唱されている21)。しかしこれらの式では寿命に影響する であろらと考兄られる32)繰り返し塑性挙動の相異が考虑 されていない，そこで MANSON の式5) 34) を用いて寿命 を計算し Table 2 飞実測值と比較して示した．計算に

Table 2. Comparison of fatigue lives between 310 $\mathrm{L}$ and $310 \mathrm{~N}$ steels under strain controlled tests at room temperature.

\begin{tabular}{|c|c|c|c|c|c|}
\hline steels & $(1 / 2)$ & $\Delta \varepsilon_{\mathrm{t}}$ & $N_{\mathrm{fc}^{1}}$ & $N_{\mathrm{fe}}^{2}$ & $N_{\mathrm{fe}} / N_{\mathrm{fc}}$ \\
\hline \multirow{4}{*}{$310 \mathrm{~L}^{3}$} & \multicolumn{2}{|c|}{ 1. $43 \times 10^{-2}$} & 788 & 2280 & 2.9 \\
\hline & 1.20 & $\prime \prime$ & 1105 & 3760 & $\begin{array}{l}2.0 \\
3.4\end{array}$ \\
\hline & & & & 3180 & 2.9 \\
\hline & $\begin{array}{l}0.97 \\
0.72\end{array}$ & $"$ & $\begin{array}{l}1680 \\
3102\end{array}$ & $\begin{array}{r}7160 \\
>13000\end{array}$ & 4. 3 \\
\hline \multirow{6}{*}{$310 N^{4}$} & \multicolumn{2}{|c|}{ 1. $43 \times 10^{-2}$} & 828 & 4410 & 5. 3 \\
\hline & 1.20 & " & 1175 & $\begin{array}{l}2870 \\
5170\end{array}$ & $\begin{array}{l}3.5 \\
4.4\end{array}$ \\
\hline & & & & 6940 & \\
\hline & 1.06 & " & 1515 & 8100 & 5.3 \\
\hline & 0.97 & $\prime \prime$ & 1824 & 9940 & 5.4 \\
\hline & 0.72 & " & 4386 & $>13000$ & - \\
\hline
\end{tabular}

Table 3. Camparison of fatigue lives between 310 $\mathrm{S}$ and 310SN steels under stress controlled tests at room temperature.

\begin{tabular}{lcccccr}
\hline steels & $\sigma_{0.2}$ & $\sigma_{\mathrm{u}}$ & $(1 / 2) \Delta \sigma_{\mathrm{a}}$ & $\sigma_{\mathrm{a}} / \sigma_{0.2}$ & $\sigma_{\mathrm{a}} / \sigma_{\mathrm{u}}$ & \multicolumn{1}{c}{$N_{\mathrm{f}}$} \\
\hline \multirow{2}{*}{$310 \mathrm{~S}$} & 229 & 531 & 343 & 1.50 & 0.65 & 2910 \\
& & & 294 & 1.28 & 0.55 & 8800 \\
\hline \multirow{3}{*}{$310 \mathrm{SN}$} & 340 & 691 & 490 & 1.44 & 0.71 & 910 \\
& & & 432 & 1.27 & 0.63 & 2440 \\
& & & 372 & 1.09 & 0.54 & 4100 \\
& & & 343 & 1.01 & 0.50 & 6590 \\
\hline
\end{tabular}

$(\sigma: \mathrm{MPa})$
必要なヤング率は AISI 310 鋼を用いた LEDBETTER $ら^{35)}$ の測定結果 $\left(18760 \mathrm{kgf} / \mathrm{mm}^{2}\right)$ を採用した．N添加 により多少この值が変わることが考兄られるが結果に及 ぼすヤング率の影響はそれ程大きくないので両鋼で同じ 值を用いた．両鋼とも測定値は計算值より大きくなつて いるが，繰り返し軟化の著しい $310 \mathrm{~N}$ 鋼のほらがその 程度が大さい。すなわち寿命の推定には繰り返し塑性挙 動も考慮されなければならないことが示唆される.

つぎに $310 \mathrm{~S}$ 鋼と $310 \mathrm{SN}$ 鋼を用いて応力一定試験を 行つた. 結果を Table 3 に示す. $0.2 \%$ 耐力 $\left(\sigma_{0.2}\right)$, 引張強さ $\left(\sigma_{\mathfrak{u}}\right)$ が高いだけに同じ応力振幅 $\left(1 / 2 \times \Delta \sigma_{\mathrm{a}}\right)$ で比較すれば 310SN 鋼のほうが 寿命が 長い。しかし $0.2 \%$ 耐力あるいは引張強さに対する応力振幅の比が汪 ぼ等しいところで比較すると， $310 \mathrm{~N}$ 鋼の寿命のほらが 短いことがわかる．これは，繰り返し軟化する場合応力 一定試験ではひずみ振幅が増大するので 1 サイクルの変 形で材料に与えられる変形ェネルギーが増すことと関連 しているものと考兄られる.

\section{4. 結論}

$18 \mathrm{Cr}-8 \mathrm{Ni} ， 25 \mathrm{Cr}-20 \mathrm{Ni}$ 系ステンレス鋼の低サイクル 疲労挙動を拈もに室温に拈いて調べ以下のような結論を 得た.

1）程度の差はあるもののすべての供試鋼で初期繰り 返し硬化ののちに繰り返し軟化することが認められた. $\mathrm{N}, \mathrm{C}$ の固溶はこの繰り返し軟化を増大させるが，とく にNの効果が著しい。

2) 大きな繰り返し軟化が認められる鋼の繰り返し変 形材の転位配列は扰もに平面状であり，他の鋼の転位配 列は打もにセルまたはバンド状であつた.

3）繰り返し軟化はとくに試験片の表面層で激しく生 じる．また大きな繰り返し軟化が認められる鋼における ほど試験片表面にすべり帯がより多く観察された。

4) 繰り返し変形によつて平面状の転位配列が生じる 場合，圧縮時の塑性ひずみ（R) を大きくとるほどいわ ゆるバウシンガー効果と同様の効果が繰り返し変形にと もなつて大きくなることが認められた．また平面状の転 位配列が生じる場合, 可動転位密度が繰り返し変形にと もなつて増加して繰り返し軟化に寄与する可能性も示唆 された.

5）転位が平面状に配列するかセルまたはバンド状に 配列するかは, 従来報告されている s. f. e. の值だけか らでは説明できない。

6) 本研究で観察された顕著な繰り返し軟化は, 疲労 寿命を長くする方向に作用する．ただし応力一定試験に 
おいては $0.2 \%$ 耐力あるいは引張強さに対する応力振 幅の比がほぼ等しいところで比較すると, 顕著な繰り返 し軟化を示す鋼の寿命は繰り返し軟化の小さな鋼の寿命 より短い.

終わりに供試鋼の準備に御助力いただいた日本治金工 業(株)の根本力男課長, 高橋博喜氏, 金属材料技術研究 所の中川龍一所長, 河部義邦博士, 高橋順一氏, 吉松史 郎部長はじめ工業化研究部の方々に深謝致します。また 研究費の一部は 文部省科学研究費補助金（昭和 55,56 年度一般研究 B ）によつたことを付記し感謝致します。

\section{交献}

1) $M$. Klesnil and $P$. Lukas: Fatigue of Metallic Materials (1980), p. 9 [Publishing Hause of the Czechoslovak Academy of Sciences]

2) H. B. Zeedijk: Metal Sci., 11 (1977), p. 171

3 ) $H$. Addel-Raouf, $A$. Plumtree, and $T$. $H$. TOPPER: Metall. Trans., 5 (1974), p. 267

4 ) $N$. Nagata, $K$. Furuya, and $R$. Watanabe: J. of Nuclear Met., 85, 86 (1979), p. 839

5 ) S. S. Manson: Proc. of lst Int. Conf. on Fracture, 3 (1965), p. 1387

6 ) $J$. Polak, $M$. Klesnil, and $P$. Lukas: Mat. Sci. Eng., 15 (1974), p. 231

$7) K$. Kanazawa and $S$. Yoshida: Greep and Fatigue in Elevated Temperature Applications (1974), p. 266 [Inst. Mech. Eng., London]

$8) K$. Nishiwaki, $N$. Owada, $K$. Hinode, $S$. Tanigawa, $K$. Shibata, $T$. Fujita, and $M$. Doyama: Proc. of 5th Int. Conf. on Positron Annihilation (1979), p. 177

9) $P$. Lukas and $M$. Klesnil: Physica Status Solidi, 21 (1967), p. 717

10) P. R. Swann: Corrosion, 19 (1963), p. 102

11）堀部 進，佐川竜平，藤田利夫，荒木 透：鉄と 鋼, 65 (1979), p. 80

12) 堀部 進, 佐川竜平, 藤田利夫, 荒木 透：鉄と 鋼, 64 (1978), p. 268

13）長谷川正：日本金属学会報，15 (1976)，p. 509
14) M. C. Mataya and $R . A$. Fournelle: Metall. Trans., 9A (1978), p. 917

15）鈴木秀次：金属の強さ (1972)，p. 10 [アグネ]

16) A. J. MaEvily and T. L. Johnston: Int.J. Fract. Mech., 3 (1967), p. 45

17) $W . J$. Plumbridge and $D . A$. Ryder: Metallurgical Rev., 14 (1969), p. 119

18) $P$. Lukas and $M$. Klesnil: Physica Status Solidi, 37 (1970), p. 833

19) C. E. Feltner and C. Laird: Acta Metall., 15 (1967), p. 1633

20) $P$. Lukas and $M$. Klesnil: Mat. Sci. Eng., 11 (1973), p. 345

21) S. KocÁNDA (石井, 田中訳)：金属疲労の解析と 応用 (1981)，p. 200 [現代工学社]

22) C. E. Feltner and $C$. Laird: Trans. Metall. Soc. AIME, 242 (1968), p. 1253

23) $P . J$. Brofman and $G . S$. Ansell: Metall. Trans., 9A (1978), p. 879

24) C. G. Rhodes and $A$. W. Thompson: 同上, 8A (1977), p. 1901

25) C. C. Bampton, $I$. P. Jones, and $M . H$. Loretto: Acta Metall., 26 (1978), p. 39

26) R. E. Stoltz and $J . B$. VAnder SANde: Metall. Trans., 11A (1980), p. 1033

27) $M$. Fujikura, $K$. Takada, and $K$. Ishida: Trans. ISIJ, 15 (1975), p. 464

28) D. L. Douglas, G. Thomas, and $W . R$. Roser: Corrosion, 20 (1964), p. $15 \mathrm{t}$

29）西沢泰二：日本金属学会報，12 (1973)， p. 401

30）加藤哲男, 藤倉正国, 矢萩慎一郎, 石田清仁：鉄 と鋼，67 (1981)，p. 587

31) R. W. Landgraf: Achievement of High Fatigue Resistance in Metals and Alloys, ASTM STP467 (1970), p. 3 [ASTM]

32) C. E. Feltner and P. Beardmore: 同上, p. 77

33）石川圭介，平賀啓二郎：日本金属学会報，20 (1981)，p. 692

34) S. S. MAnson: Experimental Mechanics, 5 (1965) 7, p. 193

35) $H$. M. Ledbetter, $W . F$. Weston, and $E . R$. Naimon: J. Appl. Phys., 46 (1975), p. 3855 